\title{
UPAYA MENINGKATKAN PSIKOMOTORIK SISWA PADA PEMBELAJARAN BOLA KASTI MELALUI PERMAINAN LEMPAR TANGKAP BOLA DI KELAS IV SDN 2 BATU BUIL
}

\author{
Herkulanus Santoso ${ }^{1}$, Indria Susilawati ${ }^{2}$, Nur Moh Kusuma Atmaja ${ }^{3}$ \\ ${ }^{1}$ Mahasiswa Program Studi Penjaskesrek Tahun 2019 \\ 2 Dosen STKIP Melawi \\ ${ }^{3}$ Dosen STKIP Melawi \\ Email: herkulanusherkulanus98@gmail.com, indria@yahoo.com, \\ atmajanur27@gmail.com
}

\begin{abstract}
The purpose of this study is to improve psychomotor in students or basic movements in the learning of the ball in the study of physical and health education in class IV SDN 2 Batu Buil with a total of 16 students. The research method used is class action research (PTK) consisting of two cycles. There are also steps in the cycle: planning, implementation, observation, and reflection. With the research subject of grade IV students and research object of SDN 2 Batu Buil. The results of the study on Cycle 1 with a total value of 1057.06 on average 66.06 and a submission of $43.75 \%$. Cycle 2 with the amount of 1371.39 average value of 85.71 and the submission of $93.75 \%$. Then there was an increase from cycle 1 to cycle 2 with a 50\% submission. In conclusion, by applying ball throwing games, kasti ball learning activities can be increased.
\end{abstract}

Keywords: ball throwing games, ball games

\begin{abstract}
Abstrak : Tujuan pada penelitian ini adalah untuk meningkatkan psikomotor pada siswa atau gerak dasar dalam pembelajaran bola kasti melalui pelajaran pendidikan jasmani dan kesehatan di kelas IV SDN 2 Batu Buil. Metode penelitian yang digunakan adalah Penelitian Tindakan Kelas (PTK) yang terdiri dari dua siklus. Ada pun langkah-langkah dalam siklus tersebut yaitu perencanaan, pelaksanaan, dan refleksi. Dengan subjek penelitian siswa kelas IV SDN 2 Batu Buil dan objek penelitian SDN 2 Batu Buil. Hasil penelitian pada siklus 1 dengan nilai total 1057,06 rata-rata 66,06 dan ketuntasan 43,75\%. Siklus 2 dengan jumlah nilai 1371,39 rata-rata 85,71 dan ketuntasan 93,75\%. Maka terjadi peningkatan dari siklus 1 ke siklus 2 dengan ketuntasan $50 \%$. Kesimpulannya dengan menerapkan permainan lempar tangkap bola, aktivitas pembelajaran bola kasti dapat meningkat.
\end{abstract}

Kata kunci : Permainan lempar tangkap bola, Permainan bola kasti. 
B anyak sekali jenis permainan bola kecil di Indonesia. Salah satunya adalah permainan bola kasti yang sudah terkenal dan populer di Nusantara. Kasti salah satu jenis permainan bola kecil beregu. Kasti merupakan bentuk permainan tradisional yang didalamnya mengutamakan beberapa unsur keterampilan seperti kekompakan, ketangkasan, kecepatan, kelincahan, serta kegembiraan.

Pengertian kasti sebenarnya sudah cukup lama kita kenal, permainan tersebut dimainkan oleh anak-anak (Deni Kurniadi, Suro Prapanca, BSE, Penjasorkes Kelas IV, 2003 : 3). Menurut Iwan Ridwan dan Ikman sulaeman (2008 : 12) Kasti merupakan salah satu jenis permainan bola kecil. Permainan ini mengutamakan kegembiraan dan ketangkasan para pemainnya. Permainan kasti sangat mengandalkan kerjasama pemain dalam satu regu atau tim untuk memenangkan permainan.

Permainan bola kasti biasanya dimainkan di lapangan terbuka. Pada tingkat anak sekolah dasar permainan ini dapat melatih kedisiplinan diri serta dapat memupuk rasa kebersamaan dan solidaritas antar teman. Dalam permainan kasti ada beberapa keterampilan yang harus dimiliki oleh setiap pemain diantaranya seperti memukul bola kasti, menangkap bola kasti, melempar bola kasti serta tidak kalah pentingnya kemampuan dalam berlari.

Permainan kasti memiliki rentang waktu yang cukup panjang dan membutuhkan gerak seluruh tubuh. Gerakan yang digunakan dalam permainan kasti diantaranya gerak lokomotor, gerak non lokomotor serta gerak manipulatif. Hampir seluruh otot-otot tubuh bekerja keras pada waktu bermain kasti. Bagian tubuh yang bekerja lebih keras yaitu otot kaki dibandingkan dengan otot-otot yang lainnya karena digunankan untuk berlari,mengejar bola, mengejar lawan, menghindari lawan.

Permainan kasti adalah permainan yang sudah merakyat dan permainannya pun mudah dan murah untuk dimainkan. Peraturan dalam permainan kasti selalu berbeda disetiap daerah masing-masing. Akan tetapi hal tersebut tidak mengurangi manfaat, nilai-nilai moral yang terkandung didalamnya atau pun semangat berolahraga tentunya dalam permainan bola kasti pada anak tingkat sekolah dasar.

Berdasarkan pengamatan peneliti selama melakukan kegiatan proses pembelajaran pendidikan jasmani dan kesehatan dalam permainan bola kasti di SDN 2 Batu Buil, siswa mendapatkan 
kesulitan untuk menerapkan dan mengembangkan keterampilan bermain kasti seperti memukul, menangkap serta melempar bola kasti.

Hal ini disebabkan belum terbentuknya koordinasi gerak yang dimiliki siswa tersebut. Selanjutnya kendala yang dihadapi adalah minimnya sarana atau alat untuk mendukung pembelajaran permainan kasti contohnya bola kasti hanya ada 4 dan pemukul kasti hanya ada 1 yang mengakibatkan siswa kurang optimal dalam proses pembelajaran permainan kasti dan waktu belajar siswa kurang efektif.

Ada pun keterampilan yang sangat penting dalam permainan bola kasti yang harus dimiliki oleh siswa adalah keterampilan memukul bola, menangkap bola serta melempar bola. Dengan memiliki keterampilan memukul bola, menangkap bola dan melempar bola yang baik diharapkan permainan bola kasti dapat dimainkan dengan baik dan benar serta menyenangkan. Sebagai seorang guru olahraga dapat menyiapkan diri untuk melatih dan membimbing siswanya agar tercapainya suatu proses pembelajaran yang diinginkan dalam permainan bola kasti.

Pendidikan jasmani olahraga dan kesehatan yang diajarkan disekolah memiliki peran yang sangat penting diantaranya melibatkan siswa secara langsung dalam berbagai pengalaman belajar melalui aktivitas jasmani olahraga dan kesehatan yang terpilih yang dilakukan secara sistematis.

Ada pun permainan yang dapat melatih gerak dasar atau psikomotor seperti memukul, melemper, dan menangkap pada anak adalah permainan lempar tangkap bola. Permainan lempar tangkap bola adalah salah satu bentuk permainan yang mengkobinasikan gerakan melempar, memukul, dan menangkap serta berlari. Ada pun manfaat atau keunggulan dalam permainan lempar tangkap bola ini adalah untuk melatih ketangkasan, konsentrasi, dan melatih otot tangan.

Berkaitan dengan psikomotor menurut Suprijono (2013:7) hasil belajar adalah perubahan perilaku secara keseluruhan bukan hanya salah satu aspek potensi kemanusiaan saja. Menurut Jihad dan Haris (2012:14) hasil belajar merupakan pencapaian bentuk perubahan perilaku yang cenderung menetap dari ranah kognitif, afektif, dan psikomotorik dari proses belajar yang dilakukan dalam waktu tertentu. Menurut Hamalik (2004:31) hasil belajar adalah pola-pola perbuatan, nilainilai, pengetahuan-pengetahuan, sikapsikap, apresiasi, abilitas, dan keterampilan. Menurut Sudjana (2009:3) mendefinisikan hasil belajar siswa pada hakikatnya adalah perubahan tingkah laku sebagai hasil 
belajar dalam pengertian yang lebih luas mencakup bidang kognitif, afektif, dan psikomotorik. Menurut Thursan Hakim (2000:1) belajar adalah suatu proses perubahan didalam kepribadian manusia, dan perubahan tersebut ditampakkan dalam bentuk peningkatan kualitas dan kuantitas tingkah laku seperti kecakapan, pengetahuan, sikap, kebiasaan, pemahaman, keterampilan, daya pikir dan lain-lain. Menurut Soedijarto (2003:6) hasil belajar adalah tingkat penguasaan yang dicapai oleh pelajar dalam mengikuti program belajar mengajar sesuai dengan tujuan pendidikan.

Ada beberapa pendapat para ahli tentang definisi tentang belajar. Menurut Cronbach, Harold Spears dan Geoch dalam sardiman A.M (2005:20). Menurut Cronbach memberikan definisi belajar adalah memperlihatkan perubahan dalam perilaku sebagai hasil dari pengalaman. Menurut Harold Spears memberikan batasan belajar adalah mengamati, membaca, berinisiasi, mencoba sesuatu sendiri, mendengarkan, mengikuti petunjuk/arahan. Menurut Geoch mengatakan belajar adalah perubahan dalam penampilan sebagai hasil praktek.

Pendidikan jasmani olahraga dan kesehatan merupakan media untuk lebih mengembangkan keterampilan motorik, kemampuan fisik, pengetahuan, penalaran, penghayatan nilai yaitu sikap, mental, emosional dan sosial. Olahraga juga merupakan salah satu alat sosialisasi yang efektif bagi masyarakat karena dalam olahraga akan terjadi kontak sosial dengan adanya komunikasi antar individu maupun kelompok sehingga akan mengenal satu sama lain.

\section{Tujuan Penelitian}

Ada pun tujuan yang akan dicapai adalah untuk mengetahui sejauh mana peningkatan kemampuan keterampilan siswa dalam keterampilan memukul, menangkap dan melempar bola kasti.

\section{Kerangka Berpikir}

Pembelajaran yang baik adalah pembelajaran yang mampu melibatkan siswa atau peserta didik dalam proses pembelajaran sesuai dengan konsep yang dipelajari. Permasalahan yang sering dihadapi dalam pembelajaran pendidikan jasmani olahraga dan kesehatan secara umum masih banyak siswa atau peserta didik yang belum mampu menganalisa atau mengolah gerakan baik secara praktek maupun teori.

\section{Metode Penelitian}

Bentuk atau model penelitian tindakan kelas (PTK) ini menggunakan model Agus Kristiyanto (2010 : 55) yang setiap siklus atau penelitiannya terdiri atas empat langkah yaitu perencanaan, tindakan, observasi, dan refleksi.

\section{Subjek dan Objek Penelitian}


Subjek penelitian adalah seluruh siswa kelas IV SDN 2 Batu Buil yang berjumlah 16 orang terdiri dari jumlah putra 8 orang dan putri 8 orang.

Objek penelitian ini adalah penerapan media permainan bola kasti didalam pembelajaran untuk mencapai hasil yang baik dan benar.

\section{Waktu Penelitian.}

Waktu penelitian dilaksanakan saat kegiatan proses belajar mengajar berlangsung dikelas IV SDN 2 Batu Buil. Siklus 1 dilakukan pada tanggal 20 September 2019 dan siklus 2 tanggal 27 September 2019.

\section{Hasil Penelitian}

Hasil penelitian pada siklus 1 nilai tertinggi 85,71 dan nilai terendah 42,85 dengan nilai total 1057,06 rata-rata 66,06 dan ketuntasan 43,75 \%. Siswa yang mendapat nilai 85,71 sebanyak 2 orang $(12,5 \%)$, nilai 78,57 sebanyak 1 orang $(6,25 \%)$, nilai 71,42 sebanyak 4 orang (25\%), nilai 64,28 sebanyak 4 orang (25\%), nilai 57,14 sebanyak 3 orang $(18,75 \%)$, nilai 50 sebanyak 1 orang $(6,25 \%)$, nilai 42,85 sebanyak 1 orang $(6,25 \%)$.

Pada siklus 2 nilai tertinggi 100 dan nilai terendah 6428 dengan jumlah nilai total 1371,39 rata-rata 85,71 dan ketuntasan $93,75 \%$. Siswa yang mendapat nilai 100 sebanyak 4 orang (25\%), nilai 92,85 sebanyak 2 orang (12,5\%), nilai 85,71 sebanyak 2 orang 12,5\%), nilai 78,57 sebanyak 7 orang $(43,75 \%)$, nilai 64,28 sebanyak 1 orang $(6,25 \%)$. Pada penelitian siklus II ini setiap nilai siswa mengalami peningkatan dan berhasil mencapai nilai KKMyang diharapkan. Maka terjadi peningkatan dari siklus 1 ke siklus 2 dengan ketuntasan $50 \%$.

Dari jumlah 16 siswa hanya sebanyak 15 siswa yang berhasil atau tuntas dalam pembelajaran permainan bola kasti yang sesuai dengan penilaian KKM. 1 orang siswa masih dinyatakan gagal atau belum tuntas dikarenakan siswa tersebut dari segi fisik juga masih kurang, kelincahan kurang, didalam proses belajar mengajar anak ini juga masih dikatakan kurang bersemangat. Walaupun belum $100 \%$ yang berhasil atau tuntas tetapi $93,75 \%$ sudah terlaksana dengan baik dan hasilnya sangat memuaskan.

\section{Simpulan}

Berdasarkan hasil penelitian terhadap kemampuan psikomotoratau teknik dasar dalam pembelajaran bola kasti pada pelajaran pendidikan jasmani dan kesehatan di kelas IV SDN 2 Batu Buil dapat disimpulkan sebagai berikut : 1. Hasil dari penelitian yang telah dilakukan dapat disimpulkan bahwa pembelajaran bola kasti pada siswa kelas IV SDN 2 Batu Buil meningkat dengan diterapkannya permainan lempar tangkap bola. 2. Permainan lempar tangkap bola sangat berpengaruh sebagai 
alternatif untuk meningkatkan hasil pembelajaran bola kasti, hal ini dapat dilihat dari hasil penelitian yaitu pada siklus 1 nilai tertinggi 85,71, nilai rata-rata 66,06, nilai total 1057,06 ketuntasan 43,75 $\%$. Siklus 2 nilai tertinggi 100 , nilai ratarata 85,71 , nilai total 1371,39 ketuntasan $93,75 \%$. Maka dengan demikian terjadi peningkatan dari siklus 1 ke siklus 2 dengan ketuntasan $50 \%$.

\section{Daftar Pustaka}

Faruq, Muhammad Muhyi. 2008. Meningkatkan Kebugaran Tubuh Melalui Permainan dan Olahraga. Surabaya : Grasindo

Hadziq, K dan Musadad, A. 2016. Penjas Orkes: Pendidikan Jasmani Olahraga dan
Kesehatan untuk Siswa SD/MI Kelas IV - V. Bandung: Yrama Widya.

Lutan, Rusli, dkk. 2013. Pendidikan Kebugaran Jasmani. Jakarta : Direktorat Jenderal Olahraga.

Suherman, Slamet dan Subagio Hartoko. 1984. Permainan Bola Kecil. Surakarta: Universitas Sebelas Maret Surakarta.

Tamat, Tisnowati, dan moekarto Mirman. 1999. Materi Pokok Pendidikan Jasmani dan kesehatan . Jakarta: Universitas Terbuka. www.karyatulisku.com pengertian hasil belajar

www.sarjanaku.com hasil belajar psikomotorik

https://permainananakunik.blogspot.com/20 14/11/lempar tangkap bola https://satyaningdharma.blogspot.com / 2014 / 03 / bermain lempar tangkap bola htpps://www.materiolahraga.com 